\title{
Rye Mulch Management Affects Short-term Indicators of Soil Quality in the Transition to Conservation Tillage for Cabbage
}

Maren J. Mochizuki ${ }^{1}$, Anusuya Rangarajan ${ }^{2}$ and Robin R. Bellinder Department of Horticulture, Cornell University, 22 Plant Sci. Bldg., Ithaca, NY 14853

Harold M. van Es

Department of Crop and Soil Sciences, Cornell University, 235 Emerson Hall, Ithaca, NY 14853

\section{Thomas Björkman \\ Department of Horticultural Sciences, New York State Agricultural Experiment Station, Cornell University, Geneva, NY 14456}

Additional index words. cover crop, soil aggregate stability, soil compaction, soil health, Brassica oleracea var. capitata, vegetable

\begin{abstract}
If benefits of conservation tillage can be quantified even in the transition year from conventional tillage, growers will more likely integrate practices that maintain or enhance soil quality and productivity. The management of surface residue is an important component of conservation tillage, especially in cool, rainy climates where vegetable growth and yield reductions have been observed when heavy residue is present. Cereal rye (Secale cereale L.), grown until flowering, was killed with glyphosate and was then cut and removed (stubble treatment) or rolled or chopped to form a surface mulch (mulched treatment) before transplanting cabbage. Rolled mulch increased soil wet aggregate stability by $4 \%$ and reduced soil penetrometer resistance by up to $0.5 \mathrm{MPa}$ compared with rye stubble treatments in 2003. In 2004, frequent rains saturated soils and may have accelerated the decomposition of chopped mulch, minimizing treatment effects. Rolled mulch reduced soil temperatures by up to $2^{\circ} \mathrm{C}$ in 2003 , but June transplanting of cabbage probably minimized the impact of soil temperature. Mulched treatments did not delay cabbage maturity or affect head quality characteristics such as color or uniformity. Although rolled mulch reduced cabbage growth by as much as $30 \%$ and yield by $21 \%$ in 2003, chopped mulch did not affect growth or yield in 2004 . Yield reduction may be overcome by killing the rye relatively early in the spring or retaining only the surface stubble; these strategies may maintain or measurably improve soil quality even in the transition year to conservation tillage.
\end{abstract}

Conservation tillage systems minimize soil disturbance and maintain $30 \%$ cover with surface residue (SSSA, 2005). Despite potential improvements in soil physical and biological properties, the adoption of conservation tillage practices for vegetable crops in the Northeast has been slow. Early research reported harvest delays and yield reductions for crops such as winter squash, tomatoes, and peppers in areas with cold, wet weather (Loy et al., 1987; McKeown et al., 1988;

Received for publication 13 Sept. 2007. Accepted for publication 4 Dec. 2007

We thank Betsy Ingall, Steve McKay, William Ketchum, and Dave Becker for on-farm technical support and Karen Grace-Martin and Francoise Vermeylen for statistical consultation.

${ }^{1}$ Current affiliation: University of California Cooperative Extension, 669 Country Square Dr., Ventura, CA 93003.

${ }^{2}$ To whom reprint requests should be addressed; e-mailar47@cornell.edu
(Garwood et al., 1999) in field trials after rye cover cropping.

Rye is often used in the Northeast because it is winter hardy and can be planted relatively late (Stivers-Young, 1998). Rye scavenges the remaining soil nitrogen (Johnson and Hoyt, 1999; Stivers-Young, 1998), resulting in reduced nitrate leaching compared with nonmulched plots (Jackson et al., 2003). Rye surface mulch also increases soil microbial biomass (Jackson et al., 2003), suppresses weeds similar to herbicide-treated plots (Bottenberg et al., 1997), and has lower insect pests in conservation tillage systems (Bottenberg et al., 1997).

If soil quality benefits can be demonstrated early in the transition to conservation tillage with minimal or no crop yield reduction, growers will more likely to integrate these practices for vegetable crops. We examined the individual components of conservation tillage-the reduction of tillage, reported in a separate paper, Mochizuki et al. (2007), and in the concurrent study discussed here, the management of surface residue. We evaluated strategies with the potential to overcome initial vegetable yield reductions in the transitional year from conventional tillage, hypothesizing that dense surface residue would increase aggregate stability, reduce compaction, and increase soil water content, and natural decomposition of the mulch would eliminate negative impacts on cabbage growth and yield.

\section{Materials and Methods}

Treatments and experimental design. Cereal rye was seeded at a rate of $190 \mathrm{~kg}$. $\mathrm{ha}^{-1}$ during the fall before each planting year at the Homer C. Thompson Vegetable Research Farm at Freeville, New York $\left(42^{\circ} 31^{\prime} \mathrm{N}, 76^{\circ} 20^{\prime} \mathrm{W}\right)$. In late May, the welldeveloped rye (head stage, $2828 \mathrm{~kg} \cdot \mathrm{ha}^{-1}$ dry weight in 2003 and $3308 \mathrm{~kg} \cdot \mathrm{ha}^{-1}$ in 2004 ) was sprayed with glyphosate $\left(0.26 \mathrm{~L} \cdot \mathrm{Ha}^{-1}\right)$ to kill the plants and roots and to provide some weed control in the field. The rye was then cut on one-half the plots using a pull-type forage harvester (New Holland; New Holland, PA) so that 2 to $4 \mathrm{~cm}$ of intact rye and roots or "stubble" remained; the cut rye, blown into a wagon trailing the harvester, was removed from the field. On the remaining plots, the standing rye was rolled flat using a roller implement (Rotavator; Howard-Konskilde, Exeter, Ontario, Canada) in 2003 and a rolling stalk chopper (Buffalo; Fleischer Manufacturing; Columbus, NE) in 2004 to form a dense surface mulch, referred to as the "mulched" treatments. The experimental design was a randomized complete block with four replications of two surface rye treatments, "stubble" and "mulched." Because the focus of this study was the transition to conservation tillage, a different field with the same soil type, Howard gravelly loam (Glossoboric Hapludalf, loamy skeletal mixed mesic), was evaluated each year. Previous crops were dry beans in 2002 and pumpkins in 2003. 
Based on the results of analytical soil fertility tests conducted in the fall before rye cover crop seeding and maximum recommendations for transplanted cabbage (Reiners, 2004), fertilizer was broadcast at a rate to provide nitrogen to the cabbage in the case of immobilization with heavy surface residue: $68 \mathrm{~kg} \cdot \mathrm{ha}^{-1}$ of $\mathrm{N}, 34 \mathrm{~kg} \cdot \mathrm{ha}^{-1}$ of $\mathrm{P}$, and $34 \mathrm{~kg} \cdot \mathrm{ha}^{-1}$ of $\mathrm{K}$ in 2003 and $68 \mathrm{~kg} \cdot \mathrm{ha}^{-1}$ of $\mathrm{N}$ and $89 \mathrm{~kg} \cdot \mathrm{ha}^{-1}$ of $\mathrm{P}$ in 2004 . An additional $68 \mathrm{~kg} \cdot \mathrm{ha}^{-1}$ of $\mathrm{N}$ as ammonium nitrate was sidedressed by hand at the cabbage cupping stage in both years.

Cabbage 'Fresco' seeds, treated with thiram, iprodione, and metalaxyl fungicides, were planted in trays with 162 cells $(50 \times$ $25 \times 3.8 \mathrm{~cm})$. Day and night temperatures in the greenhouse were about $24^{\circ} \mathrm{C}$ and $10^{\circ} \mathrm{C}$, respectively. Transplants were raised in the greenhouse for $32 \mathrm{~d}$ and were hardened in a coldframe for 1 week before planting. A notill transplanter (Model RJV600; RJ Equipment, Blenheim, Ontario, Canada) was used to plant seedlings on 9 June 2003 and 7 June 2004. Between-row spacing was $76 \mathrm{~cm}$ between plants and in-row spacing was $36 \mathrm{~cm}$ between plants. Skips or misplaced plants were transplanted by hand the next day. Each plot had four plant rows and measured $7.6 \times$ $9.1 \mathrm{~m}$.

Oxyfluorfen (2.4 L. ha ${ }^{-1}$ product) was applied pretransplant for broadleaf weed control and s-metolachlor $\left(1.2 \mathrm{~L} \cdot \mathrm{ha}^{-1}\right.$ product) was applied post-transplant for annual grass control (Reiners, 2004). Plants were scouted weekly for flea beetles (Phyllotreta cruciferae) using a damage threshold of eight beetles per plant in 2003. In 2003, permethrin $\left(0.44 \mathrm{~L} \cdot \mathrm{ha}^{-1}\right.$ product $)$ and lamda-cyhalothrin $\left(0.28 \mathrm{~L} \cdot \mathrm{ha}^{-1}\right.$ product $)$ were applied once each for control. The threshold was reduced to five flea beetles per plant in 2004, and plants were sprayed once each with carbaryl $\left(1.1 \mathrm{~kg} \cdot \mathrm{ha}^{-1}\right.$ product), endosulfan (2.4 $\mathrm{L} \cdot \mathrm{ha}^{-1}$ product), permethrin $\left(0.44 \mathrm{~L} \cdot \mathrm{ha}^{-1}\right.$ product $)$, and lamdacyhalothrin $\left(0.22 \mathrm{~L} \cdot \mathrm{ha}^{-1}\right.$ product $)$.

Irrigation to supplement rainfall in 2003 was applied three times based on gypsum moisture block readings less than 50\% saturation (model 5910A; Soil Moisture Equipment Corp., Santa Barbara, CA). No supplemental irrigation was necessary in 2004. Both seasons had higher than average precipitation. With $160 \mathrm{~mm}$ in July 2003, rainfall exceeded the 30 -year average by $78 \%$; in 2004, July (240 $\mathrm{mm})$ and August $(172 \mathrm{~mm})$ exceeded the 30 year average by $167 \%$ and $100 \%$, respectively (Northeast Regional Climate Center, 2004).

Soil wet aggregate stability. The soil was sampled 14 and $105 \mathrm{~d}$ after planting (DAP) in 2003 and 23 and 100 DAP in 2004. Two inrow and two between-row soil samples were taken per plot to a depth of $15 \mathrm{~cm}$. Each sample was mixed thoroughly and was

Table 1. Effect of surface rye mulch on the percentage of stable soil aggregates sampled to a $15-\mathrm{cm}$ depth in a gravel loam at Freeville, New York. Standing rye was cut and removed in the "stubble" treatment and was rolled or chopped (2004) in the "mulched" treatment.

\begin{tabular}{lcclcc}
\hline & \multicolumn{2}{c}{2003} & & \multicolumn{2}{c}{2004} \\
\cline { 2 - 3 } \cline { 5 - 6 } & 14 & 103 & & 23 & 100 \\
Treatment & DAP & DAP & & DAP & DAP \\
\hline Stubble & $23 \%$ & $26 \% \mathrm{~b}^{\mathrm{z}}$ & & $14 \%$ & $15 \%$ \\
Mulched & $23 \%$ & $30 \% \mathrm{a}$ & & $16 \%$ & $15 \%$ \\
$P$-value & NS & $*$ & & NS & NS \\
\hline
\end{tabular}

${ }^{\mathrm{z}}$ Mean separation in columns.

NS, *Nonsignificant or significant at $P \leq 0.05$. DAP, days after planting.
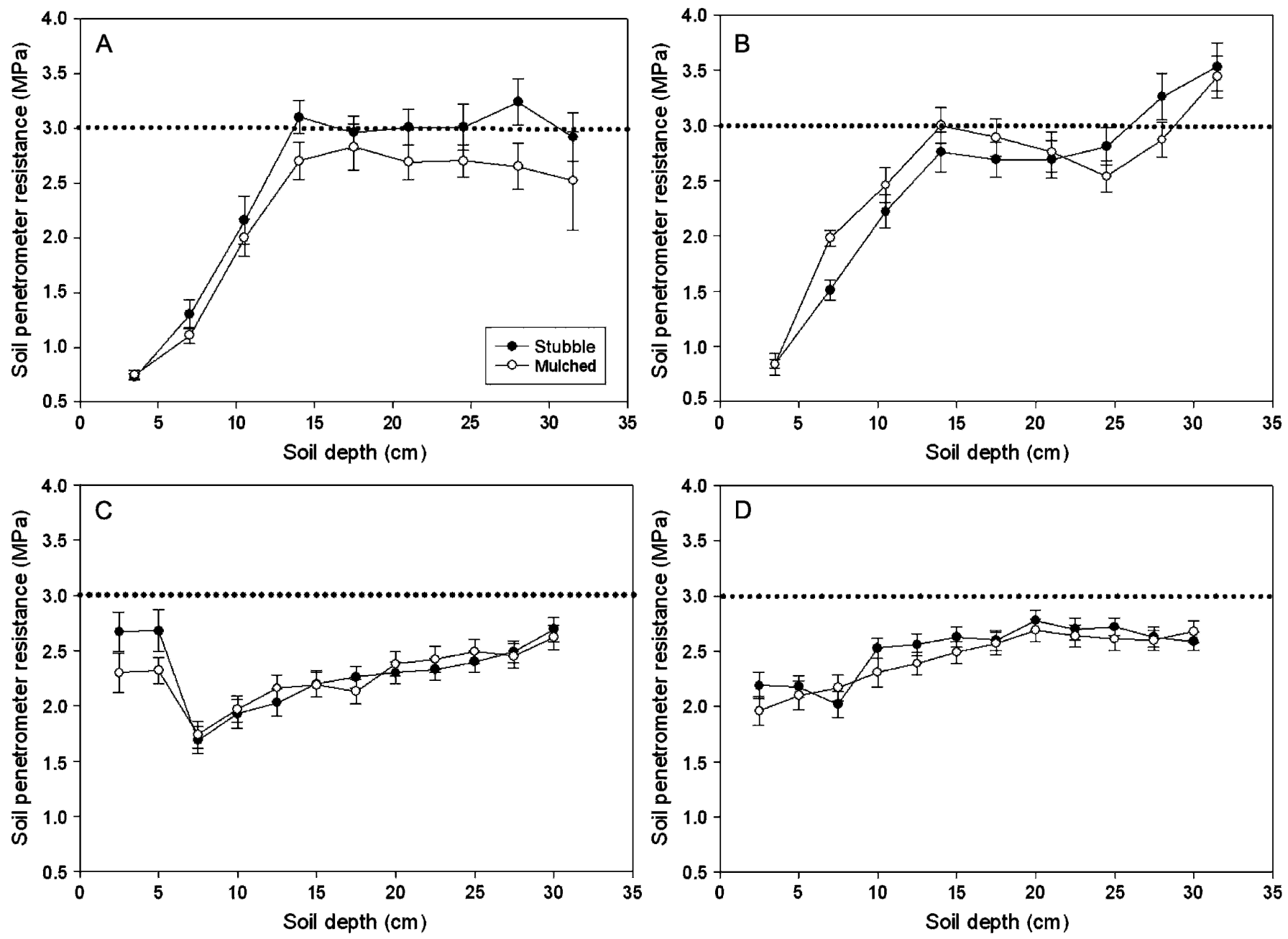

Fig. 1. Effect of surface rye mulch on soil penetrometer resistance as a function of soil depth in a gravel loam at Freeville, New York. Standing rye was cut and removed in the "stubble" treatment and was rolled or chopped (2004) in the "mulched" treatment. Data from 2003 include (A) 16 DAP and (B) 106 DAP. Data from 2004 include (C) 17 DAP and (D) 104 DAP. Standard error bars indicate the variability for the mean of each treatment and depth. The 3.0 MPa threshold above which plant growth may be limited is indicated by a dotted line. 
allowed to air dry for 24 to $48 \mathrm{~h}$. Aggregate stability was evaluated following the methods of van Es et al. (2006). Briefly, soil was separated into two aggregate fractions (2$8 \mathrm{~mm}$ and $250 \mu \mathrm{m}-2 \mathrm{~mm}$ ) by shaking for $10 \mathrm{~s}$ with U.S. standard $8-\mathrm{mm}, 2-\mathrm{mm}$, and $250-\mu \mathrm{m}$ sieves on an automated coarse sieve shaker (W.S. Tyler, St. Catharines, Ontario, Canada). The weight of the fraction larger than $8 \mathrm{~mm}$ was used to calculate the percentage of gravel content of the soil and the fraction smaller than $250 \mu \mathrm{m}$ was discarded.

A subsample of aggregate crumbs, $\approx 70 \mathrm{~g}$ of large size $(2-8 \mathrm{~mm})$ and $30 \mathrm{~g}$ of small size $(250 \mu \mathrm{m}-2 \mathrm{~mm})$, were evenly distributed on 2-mm and 250- $\mu \mathrm{m}$ sieves, respectively. The samples were subjected to simulated rainfall using the Cornell Sprinkle Infiltrometer (Ithaca, NY) for $5 \mathrm{~min}$ to deliver $2.5 \mathrm{~J}$ of energy ( $1.25 \mathrm{~cm}$ of water column), approximating the brief but intense rains common in the Northeast. The amount of aggregates remaining on the sieve surface after the rainfall simulation was corrected for the water, rock, and particulate organic matter content of the sample by weight to indicate the percentage of stable soil aggregates.

Soil water content. Gravimetric soil water content was measured 8,55 , and 105 DAP in 2003 and 23 and 100 DAP in 2004. Two inrow and two between-row soil samples were taken per plot to a depth of $15 \mathrm{~cm}$. Each sample was thoroughly mixed before removing a subsample into sealed moisture cans or plastic bags to prevent desiccation. In the laboratory, $\approx 2 \mathrm{~g}$ of soil from each can was oven-dried for 24 to $48 \mathrm{~h}$ at $61{ }^{\circ} \mathrm{C}$. The dry weight of soil was subtracted from the fresh weight; the difference was divided by the fresh weight to calculate the percent of water by weight.

Soil penetrometer resistance. Soil resistance to penetration as a function of depth was assessed by averaging three in-row measures per plot. In 2003, a Bush recording cone-tip penetrometer (Findley, Midlothian, Scotland, UK), registering every $3.5 \mathrm{~cm}$ to a depth of $31.5 \mathrm{~cm}$ was used 16 and 106 DAP. In 2004, resistance was measured 17 and 104 DAP using a Rimik CP20 recording cone-tip penetrometer (Agridry, Toowomba, Australia) every $2.5 \mathrm{~cm}$ to a depth of $30 \mathrm{~cm}$. This soil type was up to $50 \%$ stones by volume, which undoubtedly resulted in penetrometer resistance values larger than the established threshold of 3.0 MPa shown to limit plant growth in coarse-textured soils (Laboski et al., 1998).

Soil temperature. Thermocouples were installed at a soil depth of $15 \mathrm{~cm} 10$ DAP in 2003 and 1 DAP in 2004 and were connected to a AM 416 Multiplexer with a CR10X data logger (Campbell Scientific, Logan, UT.). To analyze variation within a 48 -h period, we examined bihourly temperatures at the beginning and end of an 8-d period preceding an increased rate of plant growth: 22 to 23 and 27 to 28 DAP in 2003 and 19 to 20 and 24 to 25 DAP in 2004 . To analyze variation within the entire 8-d interval, the maximum and minimum temperatures were calculated for each day between 22 and 29 DAP in 2003 and between 19 and 26 DAP in 2004. Soil temperature was measured for the entire season, but analysis of data at the middle and end of the season indicated no differences (data not shown).

Aboveground biomass sampling. Three plants per plot were destructively sampled at 14, 28, 58, and 71 DAP in 2003 and 14, 29, 44,56 , and 71 DAP in 2004. Plants were randomly chosen from the two center rows of each plot and were cut at the soil line. Each sampled plant had all neighbors intact to avoid sampling bias. Plant fresh and dry weight (after oven drying at $41{ }^{\circ} \mathrm{C}$ ) were recorded.

Harvest yield and quality. Head yield and quality were sampled from a $2.7-\mathrm{m}^{2}$ area in the center of each plot. The areas were harvested twice, 77 and 91 DAP in 2003 and 80 and 93 DAP in 2004, in case maturity was delayed in some treatments. Because there were no treatment differences in maturity, yield data from both harvests were summed for analysis. Three representative heads from each plot were cut in half to assess internal characteristics and quality. Head length and width and core length and width were measured.

Statistical analysis. Analysis of variance was performed using the SAS Mixed Procedure (SAS systems, Cary, NC). Because of significant treatment by year interactions, data were analyzed and presented within each year.

\section{Results and Discussion}

The presence of dense rye mulch increased soil aggregate stability by the end of the 2003 season (Table 1). Aggregates under rolled mulch were $30 \%$ stable compared with $26 \%$ for the stubble treatment $(P<$ $0.05)$. What constitutes meaningful differences in soil aggregation in conservation tillage using the rainfall simulation technique is not yet known; however, several studies using traditional wet sieve methods have compared heavy residue systems and reduced tillage with conventional tillage. For example, after 20 years in which conventional, no tillage, and a reduced tillage with stubble mulch was alternated with fallow, Cambardella and Elliot (1993) found a 5\% increase in aggregate stability for no tillage compared with stubble mulch for the 53- to $250-\mu \mathrm{m}$ size fraction but no differences in the other size fractions. No tillage aggregates in the 53- to $250-\mu \mathrm{m}$ size fraction were $10 \%$ more stable than conventional tillage aggregates. By con- trast, Seybold et al. (2002) found aggregate stability was increased by $40 \%$ in the 26 th year of no-till compared with conventional tillage, and Leibig et al. (2004) found that a rotation of spring wheat, winter wheat, and sunflower followed by no tillage had 35\% more stable aggregates compared with a spring wheat, fallow, conventional tillage system.

The dense surface mulch may have provided organic matter to soil microorganisms that bind soil particles in addition to the rye roots that were present in surface and stubble treatments. Aggregate stability using the traditional wet sieving technique has been correlated to soil carbon content (Stine and Weil, 2002). Furthermore, an increased proportion of macroaggregates with particulate organic matter were found in no tillage compared with conventional (Cambardella and Elliot,1993). The potential correlation to biological activity of soil aggregate stability using the rainfall simulation technique of this study must still be established.

In 2004, however, the presence of dense mulch did not affect wet aggregate stability (Table 1). Although both sampling years were wetter than average, in 2004, July and August exceeded the 30 year average by 134\% (Northeast Regional Climate Center, 2004). The heavy rains probably accelerated the decomposition of the surface mulch, minimizing its impact on soil quality. In addition, aggregate stability was less overall in 2004 compared with 2003; the physical impact of frequent rain droplets likely fragmented soil aggregates in mulched and stubble plots to the point where the treatments were indistinguishable.

Soil under dense rye mulch was up to $0.5 \mathrm{MPa}$ less resistant to penetration compared with the stubble treatment between 14 and $28 \mathrm{~cm}$ depths, 16 DAP in $2003(P<0.10$; Fig. $1 \mathrm{~A})$, likely resulting from about $1 \%$ higher water contents at the beginning and middle of the 2003 season $(P<0.0001$; Table 2$)$. By the end of 2003, there were no significant differences in resistance (Fig. 1B) or soil water content (Table 2) attributable to mulch. In 2004, differences in penetrometer resistance between mulched and stubble plots were found only at one or two soil depths, with no clear trend emerging at 17 or 104 DAP (Fig. 1, $\mathrm{C}$ and D). Similarly, there were no differences in soil water content in 2004 (Table 2), presumably because of higher-than-average precipitation that saturated soils in both treatments.

Surface residue may decrease evaporation, reduce surface runoff, and improve

Table 2. Effect of surface rye mulch on soil water content (percentage water of fresh soil by weight) sampled to a $15-\mathrm{cm}$ depth in a gravel loam at Freeville, New York.

\begin{tabular}{|c|c|c|c|c|c|}
\hline \multirow{2}{*}{ Treatment } & \multicolumn{3}{|c|}{2003} & \multicolumn{2}{|c|}{2004} \\
\hline & 5 DAP & 55 DAP & $105 \mathrm{DAP}$ & $23 \mathrm{DAP}$ & $100 \mathrm{DAP}$ \\
\hline Stubble & $13 \% b^{z}$ & $12 \% \mathrm{~b}$ & $14 \%$ & $13 \%$ & $13 \%$ \\
\hline Mulched & $14 \%$ a & $13 \%$ a & $14 \%$ & $12 \%$ & $13 \%$ \\
\hline$P$-value & $* * *$ & $* *$ & NS & NS & NS \\
\hline
\end{tabular}

${ }^{\mathrm{z}}$ Mean separation in columns.

Ns, ${ }^{* *},{ }^{* * *}$ Nonsignificant or significant at $P \leq 0.01$ or 0.001 , respectively.

DAP, days after planting. 
infiltration, all of which can increase soil water content (Raper et al., 2000; Vyn et al., 1998). Wilhoit et al. (1990) found that even small differences of $2 \%$ in soil moisture during the middle of the summer season were important to cabbage growth and yield. Par- ticularly in drier conditions, surface mulch can improve yields by preventing evaporation (Johnson and Hoyt, 1999). For example, strip-tilled cabbage with rye surface mulch had $56 \%$ higher yield than with rye stubble mulch in one dry year (Wilhoit et al., 1990).
No-tillage with standing rye yielded more pumpkins than disk tillage during an unusually hot, dry growing season (Rapp et al., 2004).

The effect of surface residue on penetrometer and soil water content is not always
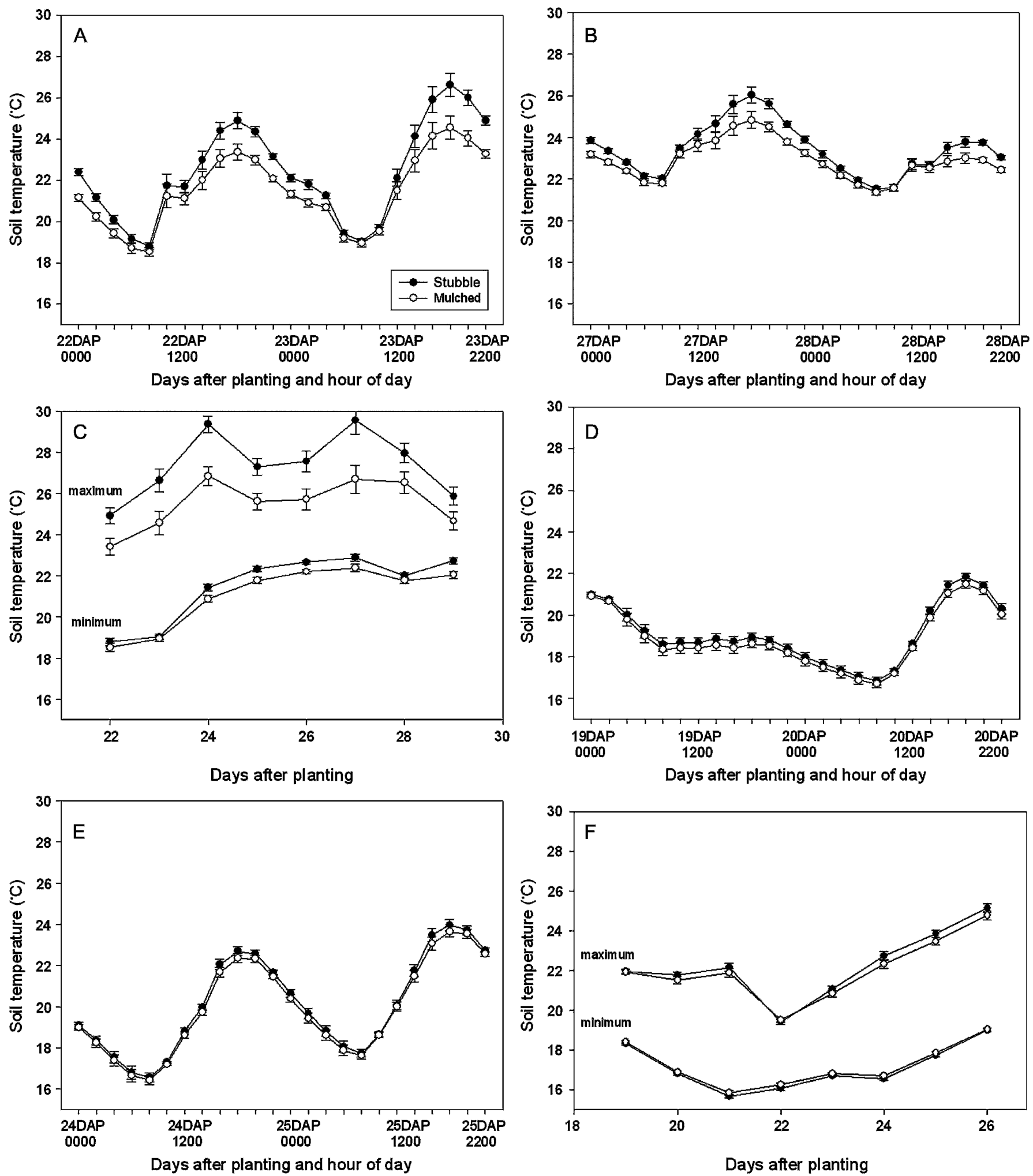

Fig. 2. Effect of surface rye mulch on soil temperature in a gravel loam at Freeville, New York. Standing rye was cut and removed in the "stubble" treatment and was rolled (2003) and chopped (2004) in the "mulched" treatment. Data from 2003 include 2-h average soil temperature (A) 22 to 23 DAP and (B) 27 to 28 DAP, and (C) daily soil temperature maximum and minimum 22 to 29 DAP. Data from 2004 include 2-h soil average temperature (D) 19 to 20 DAP and (E) 24 to 25 DAP, and (F) daily soil temperature maximum and minimum 19 to 26 DAP. Standard error bars indicate the variability for the mean of each treatment and hour or day. 
sustained in field trials, however, because of inherent variability in soil and weather conditions (Maiorana et al., 2001; Raper et al., 2000) and by the fact that leaf transpiration from a large crop canopy by the end of the season can be responsible for significant soil water loss.

Increased soil water content attributed to the presence of surface mulch may slow soil warming and reduce early plant growth and later yield of short-season vegetable crops (Hoyt, 1999). In this study, dense mulch reduced diurnal soil temperature up to $2{ }^{\circ} \mathrm{C}$ compared with stubble treatments in 2003 $(P<0.10$; Fig. $2 \mathrm{~A})$ : mulched soil was cooler in the early morning (0000-0400 HR), the afternoon (when solarization was most intense), and at night, 22 to 23 DAP (Fig. 2A) and 27 to 28 DAP (Fig. 2B). In the following year, mulched and stubble treatments were similar at both sampling dates (Fig. 2, D and E). Mulched soils had a smaller range between maximum and minimum daily temperatures even though minimum daily temperatures were cooler $(P<0.10)$ compared with the stubble treatment in 2003 (Fig. 2C); in 2004, there was no effect of mulch on soil temperature range (Fig. 2F).

The presence of dense mulch decreased plant biomass accumulation by up to $30 \%$ between 28 and 58 DAP in $2003(P<0.0001$; Table 3$)$. Even later in the season, by 71 DAP, mulched plants were $15 \%$ smaller than stubble treatment plants $(P<0.01$; Table 3$)$. There were no differences in plant size at all sampling dates in 2004 (Table 3).

Mulch did not delay maturity and harvest date in either year. Mulched treatments, however, yielded $26 \%$ less than stubble treatments in $2003(P<0.0001$; Table 4$)$, primarily because individual heads were smaller: marketable head weight for mulched cabbage was $19 \%$ lower than for stubble plots $(P<$ 0.001; Table 4). Average head width and core length were lower for mulched treatments $(P<0.05$ and 0.01 , respectively; data not shown), also reflecting smaller head size. Other quality measures such as color and uniformity were unaffected by the heavy surface residue. No differences in yield and head weight (Table 4) or head quality (data not shown) were attributed to mulch in 2004.

Soil temperature differences between mulched and stubble plots were relatively small: other researchers exploring conservation tillage for cabbage found soil temperature differences of up to $4{ }^{\circ} \mathrm{C}$ but concluded the differences were not enough to account for observed yield reductions because soil temperatures for all treatments were within optimum range for cabbage growth (Wilhoit et al., 1990) or could be attributed to other factors such as soil compaction (Bottenberg et al., 1997; Knavel and Herron, 1981).

In this study, no differences in nitrogen content were found in analyses of leaf petiole sap at cupping stage and cabbage head tissue at harvest; all samples were in sufficiency range or higher regardless of mulch treatment (data not shown). Moreover, the presence of

Table 3. Effect of surface rye mulch on cabbage aboveground fresh biomass accumulation (grams per plant) in 2003 and 2004 at Freeville, New York. Planting dates were 9 June and 7 June, respectively.

\begin{tabular}{|c|c|c|c|c|c|c|c|c|c|}
\hline & \multicolumn{4}{|c|}{2003} & \multicolumn{5}{|c|}{2004} \\
\hline & 14 DAP & 28 DAP & 58 DAP & $71 \mathrm{DAP}$ & 14 DAP & 29 DAP & 44 DAP & 56 DAP & $71 \mathrm{DAP}$ \\
\hline Stubble & $8 a^{z}$ & $98 \mathrm{a}$ & $1,237 \mathrm{a}$ & $2,586 \mathrm{a}$ & 7 & 75 & 515 & 1,145 & 1,582 \\
\hline Mulched & $6 \mathrm{~b}$ & $66 \mathrm{~b}$ & $852 \mathrm{~b}$ & $2,135 \mathrm{~b}$ & 7 & 72 & 447 & 936 & 1,360 \\
\hline$P$-value & $* *$ & $* * *$ & $* * * *$ & $* *$ & NS & NS & NS & NS & NS \\
\hline
\end{tabular}

${ }^{\mathrm{z}}$ Mean separation in columns.

Ns, ${ }^{* *},{ }^{* * *},{ }^{* * * *}$ Nonsignificant or significant at $P \leq 0.01,0.001$ or 0.0001 , respectively. DAP, days after planting.

mulch neither delayed head maturity nor affected cabbage quality parameters such as color and uniformity, which could indicate nutrient deficiency or allelopathic interference. On the other hand, smaller cabbage plants and heads in 2003 may have resulted from rye allelopathy that was minimized in 2004 with the use of an implement that cut smaller pieces of mulch and more rain, both contributing to more rapid degradation of rye allelopathic compounds compared with 2003. The amount of rye biomass may affect suppression of weed seed by physical impedance and light exclusion (Teasdale and Mohler, 2000), but likely impacts the quantity of allelochemicals present in field as well (Reberg-Horton et al., 2005). Killing the rye earlier or reducing the seeding rate such that the total biomass and therefore the level of allelochemicals is reduced or choosing a different cover crop such as hairy vetch may be alternatives to avoid allelopathic interference. However, the amount of allelochemicals present in the rye tissue also depends on cultivar, and many cultivars actually have higher amounts of allelochemicals at an earlier kill date (Reberg-Horton et al., 2005). Killing the rye earlier or reducing seeding rate to reduce total biomass, however, may limit the short-term soil quality benefits.

\section{Conclusions}

Dense surface residue provided tangible benefits to the soil that were measurable within one growing season in 1 or 2 years of study. The addition of organic matter as stubble or dense residue to conservation tillage treatments has the potential to improve soil structure and nutrient content in the long term (Johnson and Hoyt, 1999) and corroborates other conclusions that soil quality indicators are most strongly influenced by amount of residue returned to the soil (Leibig et al., 2004; Thomas et al., 1996). Maintaining surface residue for soil quality is particularly important for vegetable systems, which tend to return very little residue after harvest. Excessive precipitation may limit the ability to document soil quality improvements with surface residue during the season.

Although we measured a significant reduction in crop growth and yield in 1 year attributable to dense mulch, the importance of surface mulch must be considered in the context of the entire cropping system. When integrated with conservation tillage practices, significant reduction in the cost of field prep-
Table 4. Effect of surface rye mulch on cabbage yield and head weight at Freeville, New York.

\begin{tabular}{|c|c|c|c|c|}
\hline \multirow[b]{2}{*}{ Treatment } & \multicolumn{2}{|c|}{ Yield (T per ha) } & \multicolumn{2}{|c|}{ Head wt (kg) } \\
\hline & 2003 & 2004 & 2003 & 2004 \\
\hline Stubble & $57.0 \mathrm{a}^{\mathrm{z}}$ & 50.4 & $1.9 \mathrm{a}$ & 1.6 \\
\hline Mulched & $45.1 \mathrm{~b}$ & 46.3 & $1.6 \mathrm{~b}$ & 1.5 \\
\hline$P$-value & $* * * *$ & NS & $* * *$ & NS \\
\hline
\end{tabular}

${ }^{\mathrm{z}}$ Mean separation in columns.

Ns, ${ }^{* * *},{ }^{* * * *}$ Nonsignificant or significant at $P \leq 0.001$ or 0.0001 , respectively.

aration (Hoyt et al., 1994; Luna and Staben, 2002), fertilizer and pesticides (Magdoff and van Es, 2000), and erosion control (Hoyt et al., 1994) have been reported. These benefits can balance some potential revenue losses from initial yield reduction.

\section{Literature Cited}

Bottenberg, H., J. Masiunas, C. Eastman, and D. Eastburn. 1997. Yield and quality constraints of cabbage planted in rye mulch. Biol. Agr. Hort. 14:323-342.

Burgos, N.R. and R.E. Talbert. 2000. Differential activity of allelochemicals from Secale cereale in seedling bioassays. Weed Sci. 48:302-310.

Burgos, N.R., R.E. Talbert, K.S. Kim, and Y.I. Kuk. 2004. Growth inhibition and root ultrastructure of cucumber seedlings exposed to allelochemicals from rye (Secale cereale). J. Chem. Ecol. 30:671-689.

Cambardella, C.A. and E.T. Elliot. 1993. Carbon and nitrogen distribution in aggregates from cultivated and native grassland soils. Soil Sci. Soc. Amer. J. 57:1071-1076.

Duiker, S.W. and W.S. Curran. 2005. Rye cover crop management for corn production in the northern mid-Atlantic region. Agron. J. 97:1413-1418.

Garwood, T.W.D., D.B. Davies, and A.R. Hartley. 1999. The effect of winter cover crops on yield of the following spring crops and nitrogen balance in a calcareous loam. J. Agr. Sci. 13: $1-11$.

Hoyt, G.D. 1999. Tillage and cover residue effects on vegetable yields. HortTechnology 9:351358.

Hoyt, G.D., D.W. Monks, and T.J. Monaco. 1994. Conservation tillage for vegetable production. HortTechnology 4:129-135.

Jackson, L.E., I. Ramirez, R. Yokota, S.A. Fennimore, S.T. Koike, D.M. Henderson, W.E. Chaney, and K.M. Klonsky. 2003. Scientists, growers assess trade-offs in use of tillage, cover crops and compost. Calif. Agr. 57:48-54.

Johnson, A.M. and G.D. Hoyt. 1999. Changes to the soil environment under conservation tillage. HortTechnology 9:380-392.

Knavel, D.E. and J.W. Herron. 1981. Influence of tillage system, plant spacing, and nitrogen on head weight, yield, and nutrient concentration 
of spring cabbage. J. Amer. Soc. Hort. Sci. 106:540-545.

Laboski, C.A.M., R.H. Dowdy, R.R. Allmaras, and J.A. Lamb. 1998. Soil strength and water content influences on corn root distribution in a sandy soil. Plant Soil 203:239247.

Leibig, M.A., D.L. Tanaka, and B.J. Weinhold. 2004. Tillage and cropping effects on soil quality indicators in the northern Great Plains. Soil Till. Res 78:131-141.

Loy, S.J.W., L.C. Peirce, G.O. Estes, and O.S. Wells. 1987. Productivity in a strip tillage vegetable production system. HortScience 22:415-417.

Luna, J.M. and M.L. Staben. 2002. Strip tillage for sweet corn production: Yield and economic return. HortScience 37:1040-1044.

Magdoff, F.R. and H.M van Es. 2000. Building soils for better crops. Handbook series book 4 . Sust. Agr. Network, Beltsville, MD.

Maiorana, M., A. Castrignano, and F. Fornaro. 2001. Crop residue management effects on soil mechanical impedance. J. Agr. Eng. Res. 79:231-237.

McKeown, A.W., R.F. Cerkauskas, and J.W. Potter. 1988. Influence of strip tillage on yield, diseases, and nematodes of tomatoes. J. Amer. Soc. Hort. Sci. 113:328-331.

Mochizuki, M.J., A. Rangarajan, R.R. Bellinder, T.N. Bjorkman, and H.M. van Es. 2007. Overcoming compaction limitations to cabbage growth and yield in the transition to conservation tillage. HortScience 42:1690-1694.
Northeast Regional Climate Center. 2004. The climate of Ithaca, NY. 15 Dec. 2004. <http://www. nrcc.cornell.edu/climate/ithaca/enhanced.html $>$.

Raper, R.L., D.W. Reeves, E.B. Schwab, and C.H. Burmester. 2000. Reducing soil compaction of Tennessee Valley soils in conservation tillage systems. J. Cotton Sci. 4:84-90.

Rapp, H.S., R.R. Bellinder, H.C. Wien, and F.M. Vermeylen. 2004. Reduced tillage, rye residues, and herbicides influence weed suppression and yield of pumpkins. Weed Technol. 18:953-961.

Reberg-Horton, S.C., J.D. Burton, D.A. Danehower, G. Ma, D.W. Monks, P. Murphy, N.N. Ranells, J.D. Williamson, and N.G. Creamer. 2005. Changes over time in the allelochemical content of ten cultivars of rye (Secale cereale L.) J. Chem. Eco. 31:179-193.

Reiners, S. (ed.). 2004. Cabbage, broccoli, cauliflower and Brussels sprouts. In: 2004 Integrated crop and pest management guidelines for commercial vegetable production. 15 Mar. 2005 $<$ http://www.nysaes.cornell.edu/recommends/ 15 frameset.html $>$.

Seybold, C.A., M.D. Hubbs, and D.D. Tyler. 2002. On-farm tests indicate effects of long-term tillage systems on soil quality. J. Sust. Agr. 19:62-73.

Smeda, R.J. and S.C. Weller. 1996. Potential for rye (Secale cereale $\mathrm{L}$.) for weed management in transplanted tomatoes (Lycopersicon esculentum). Weed Sci. 44:596-602.

Soil Science Society of America. 2005. Glossary of soil science terms. Madison, WI. 15 Mar. 2005. $<$ http://www.soils.org/sssagloss/.>
Stine, M.A. and R.R. Weil. 2002. The relationship between soil quality and crop productivity across three tillage systems in south central Honduras. Amer. J. Alt. Agr. 17:2-8.

Stivers-Young, L. 1998. Growth, nitrogen accumulation, and weed suppression by fall cover crops following early harvest of vegetables. HortScience 33:60-63.

Teasdale, J.R. and C.L. Mohler. 1993. Light transmittance, soil temperature, and soil moisture under residue of hairy vetch and rye. Agron. J. 85:673-680.

Teasdale, J.R. and C.L. Mohler. 2000. The quantitative relationship between weed emergence and physical properties of mulches. Weed Sci. 48:385-392.

Thomas, G.W., G.R. Haszler, and R.L. Blevins. 1996. The effects of organic matter and tillage on maximum compactability of soils using the Proctor test. Soil Sci. 161:502-508.

van Es, H.M., R.R. Schindelbeck, A. Melkonian, B.N. Moebius, and O.J. Idowu. 2006. Assessment of soil aggregate stability using small rainfall simulators. Dept. of Crop and Soil Sci. Res. Ser. 06-01, Cornell University, Ithaca, NY.

Vyn, T.J., G. Opoku, and C.J. Swanton. 1998. Residue management and minimum tillage systems for soybean following wheat. Agron. J. 90:131-138.

Wilhoit, J.H., R.D. Morse, and D.H. Vaughan. 1990. Strip-tillage production of summer cabbage using high residue levels. Appl. Agr. Res. 5:338-342. 